\title{
Growth and Yield of Inpari 29 Rice Varieties on Raised-bed and Different Depths of Sunken-bed in Saline Field
}

\author{
Nasrudin $^{1}$ and Budiastuti Kurniasih ${ }^{2 *}$ \\ ${ }^{1}$ Postgraduate Student, Department of Agronomy, Faculty of Agriculture Universitas Gadjah Mada \\ Jln. Flora no. 1, Bulaksumur, Sleman, Yogyakarta 55281, Indonesia \\ ${ }^{2}$ Department of Agronomy, Faculty of Agriculture Universitas Gadjah Mada \\ Jln. Flora no. 1, Bulaksumur, Sleman, Yogyakarta 55281, Indonesia \\ *Corresponding email: tuti_b@ugm.ac.id
}

\begin{abstract}
Increased productivity of rice is required to meet the increasing food demand. Utilization of marginal lands, such as saline land is one of the solutions applicable to increase rice production. The objective of this research was to determine the growth and yield of Inpari 29 rice variety planted on raised-bed and different depths of sunken-bed in saline field. This research used the Split Plot Design with two treatments. The depth as the main plot consisted of two depth levels: a depth of $50 \mathrm{~cm}$ and a depth of $25 \mathrm{~cm}$; and the planting area field as the subplot consisted of two levels: raised-bed and sunken-bed. The treatment was repeated three times. The rice planted in sunken-bed showed higher growth than in raised-bed as indicated by the high content of chlorophyll a, chlorophyll b, total chlorophyll, nitrate reductase activity and plant height. The rice planted in the sunken-bed yielded higher than in raised-bed as indicated by higher harvest index and the weight of grain per clump. Rice planted in $25 \mathrm{~cm}$ depth showed higher nitrate reductase activity and grain weight per clump than in $50 \mathrm{~cm}$ depth.
\end{abstract}

Keywords: Depth, raised-bed, rice, saline field, and sunken-bed

\section{INTRODUCTION}

Rice (Oryza sativa L.) is one of the important food commodities in Indonesia as the most widelyconsumed food by the people. Rice production in 2016 was 79.35 million tons from 15.16 million $\mathrm{Ha}$ land area or $52.36 \mathrm{Ku} . \mathrm{Ha}^{-1}$ productivity (Kementerian Pertanian, 2017). Indonesia is a country with population majority that consumes rice as the staple food. The amount was equal to $114.6 \mathrm{~kg}$.capita ${ }^{-1}$.year ${ }^{-1}$ in 2016 with an increasing population growth rate of $1.49 \%$ year $^{-1}$ (Ministry of Agriculture, 2016). In order to meet such food demand, a technology that can increase rice productivity is consequently required.

Marginal land such as tidal land can be used as a strategy to increase rice productivity. Sudaryono (2017) stated that the tidal area in Indonesia can be estimated as 20.12 million Ha consisting of 2.07 million Ha of potential field, 6.72 million Ha of acid sulphate field, 10.89 million ha of peat-soil field, and 0.44 million ha of saline field. However, the land use still has to cope with various problems such as water and soil issues.

Agricultural land in Baros Village consists of fields with limiting factors such as salinity and waterlogging due to seawater overflow. Salinity is one of the major stresses in rice cultivation (Aref, 2013). It leads to water quality with high level electrical conductivity (Zeng and Shannon, 2000) and low soil fertility ( $\operatorname{Rad}$ et al., 2011). According to Rusd (2011), when the EC value of water or soil reaches over $4 \mathrm{dS} . \mathrm{m}^{-1}$, it will affect the plant growth. Salinity has various impacts on rice cultivation depending on the phase of growth, severity, and duration of stress (Radanielson et al., 2017). The effect of salinity in the soil for rice cultivation includes reduction of growth and development (Cha-um and Kirdmanee, 2010). Percentage of rice yield loss based on EC was $<10 \%, 10-20 \%, 20-50 \%$, and $>50 \%$ when EC was $<4 \mathrm{dS} . \mathrm{m}^{-1}, 4-6 \mathrm{dS} \cdot \mathrm{m}^{-1}, 6-10$ $\mathrm{dS} . \mathrm{m}^{-1}$, and $>10 \mathrm{dS} \cdot \mathrm{m}^{-1}$, respectively (FAO, 2005).

Water is an absolute need for plant to allow various 
metabolic activities. However, excessive water is the limiting factor in rice cultivation process. According to Sakagami et al. (2013) plants that are waterlogged for too long, will face disruption in photosynthesis. It will also bring yield loss by $10-100 \%$ depending on the duration of inundation, water temperature and turbidity, soil fertility, light intensity, and the plant age (Bruins et al., 2012).

Waterlogging will cause metabolic disturbances to the rice plants which consequently bring impacts on the plant growth, decreasing yield, and mortality (Rachmawati and Retnaningrum, 2013). It also leads to low levels of $\mathrm{O}_{2}$ and solar radiation in the air resulting in disrupted growth and mortality (Sarkar et al., 2006). When the water recedes, the plant returns to adapt to the environment by obtaining optimal $\mathrm{O}_{2}$ and light intensity (Ella et al., 2003). Morphologically and physiologically, most rice cultivars lengthen their stem in response to waterlogging. The elongation of the stem allows rice plants to continue the anaerobic metabolic processes and $\mathrm{CO}_{2}$ fixation (Sarkar et al., 2006; Kawano et al., 2008). Based on the research by Rachmawati and Retnaningrum (2003), waterlogging of rice plant by $8 \mathrm{~cm}$ of depth within a certain period of time increases plant height, plant biomass, and canopy root ratio. A study by Kawano et al. (2008) showed that $1-\mathrm{m}$ depth of waterlogging for 7 days increased the stem length, leaf area, and plant biomass.

To optimize the growth and production, a proper method of rice cultivation is required. One of them was by making the growth media into raised and sunken-bed. Raised-beds are part of the field that has physical, chemical and biological properties as a dry agricultural field. The soil in raised-bed is aerobic so that the cultivated plants should not need much water. Sunken-beds are part of the field with physical, chemical and biological properties that are the same as wet agricultural field with anaerobic soil atmosphere (Sasmita, 2006). The making of raised and sunken-bed are aimed to minimize crop failures due to environmental stresses such as floods, salinity, seawater overflows, and others. Raised-beds by $50-60 \mathrm{~cm}$ of height with worm ducts around the sunken-bed are used to wash the poison compounds and to avoid overflow of seawater that will inundate the rice plants (Susilawati and Nursyamsi, 2014).

The Center for Research on Sukamandi Rice has released Inpari 29 rice variety with properties suitable for lowland irrigation to $400 \mathrm{~m}$ altitude of height above sea level, especially in flood-prone areas with the total inundation of the vegetative phase of more than 14 days. This variety has a planting age of \pm 110 days after seedling, $103 \mathrm{~cm}$ of height, the average yield of 6.5 tons.ha $^{-1}$, and potential yield of 9.5 tons.ha ${ }^{-1}$ (BB Padi, 2012). Land arrangement by modifying the planting field has not been widely studied. Therefore, the use of sunken-bed (aquatic) and raised-bed (terrestrial) in different depths and heights are expected to be location-specific accurate technology for rice cultivation in the tidal field. The objective of this research was to determine the growth and yield of Inpari 29 rice variety planted on raised and sunken-bed with different depths in saline field.

\section{MATERIALS AND METHODS}

This research was carried out from February to July 2017 at Baros Sub-Village, Tirto Hargo Village, Kretek District, Bantul Regency, which is located 4 $\mathrm{m}$ above sea level. It includes a marginal tidal field with overflow type A. Small tide occurrs twice a day: in the morning and evening, with a water level of $\pm 30 \mathrm{~cm}$ in sunken-bed of $50 \mathrm{~cm}$ of depth. Big tides submerged plants in the sunken and raised-bed. It occurred four times, on March 31, and April 1, 29 and 30, 2017.

Based on the data by BMKG 2017, the average monthly temperature of the command area ranged from $26.3-26.6^{\circ} \mathrm{C}$ with $81-86 \%$ of humidity and monthly rainfall between 13-325 mm.month ${ }^{-1}$. According to Mareja (2015) suitable climate for rice cultivation was between $22-27^{\circ} \mathrm{C}$ with $50-90 \%$ of humidity and $200 \mathrm{~mm} . \mathrm{month}^{-1}$ monthly rainfall. Based on the climate data above, such conditions were suitable for rice cultivation. However, monthly rainfall in May and June was quite low, each of which was $23 \mathrm{~mm} . \mathrm{month}^{-1}$ and $13 \mathrm{~mm}$. month $^{-1}$, respectively. This caused the high electrical conductivity of water due to seawater which was pushed into the research area through river flow more than brackish water.

Experiments used split-plot design and carried out by two treatments. The depth as the main plot consisted of two levels: a depth of $50 \mathrm{~cm}$ (A1) and a depth of $25 \mathrm{~cm}$ (A2). The planting area field as the sub-plot consisted of two levels: raised-bed $(G)$ and sunken-bed (L). Raised-bed is a planting area field with limited water and sunken-bed is a planting area field with adequate water availability. Raised-bed is beside the sunken-bed. The treatment was repeated three times. Destructive observation was carried out on week 3 , week 6 , and the harvest time. The research used Inpari 29 variety which was resistance 
to submergence.

Soil processing included plowing and making excavations into two fields: raised and sunken-bed of $25 \mathrm{~cm}$ and $50 \mathrm{~cm}$ depth. Experiment of sunken-bed was $1 \times 3 \mathrm{~m}$ for each. Together with plowing, manure was given at a dose of 2 tons. $\mathrm{Ha}^{-1}$. Sowing was carried out on saline bed nursery by $1 \times 1 \mathrm{~m}$ for each variety and allowed to grow for 30 days after seedling. Transplanting was done by planting four plants in each hole by $20 \times 20 \mathrm{~cm}$ spacing manually. Plant maintenance included the weeding, pest and disease control, irrigation, and fertilization by applying urea, SP-36, and $\mathrm{KCl}$ in a dose of 150, 100 and 50 kg.ha ${ }^{-1}$ in 21 days after planting and $75 \mathrm{~kg}$. $\mathrm{Ha}^{-1}$ urea and 50 kg.ha ${ }^{-1} \mathrm{KCl}$ in 42 days after planting. Harvest was carried out 86-88 days after planting.

Parameters observed included leaf area $\left(\mathrm{cm}^{2}\right)$, measured by placing leaves under the camera in the leaf area meter, then grabbed and measured in the winDIAS 3 version 3.2.1 application. Observation of leaf area was carried out when plants were 3 and 6 weeks after planting. Photosynthesis rate $(\mu \mathrm{mol}$ $\mathrm{CO} 2 . \mathrm{m}^{-2} \cdot \mathrm{s}^{-1}$ ) was measured by clamping the leaves using a LiCOR Li-6400 portable photosynthesis system and photosynthesis will appear on the screen of the device. Photosynthetic rate was carried out when plants were 6 weeks after planting. Contents of chlorophyll a, chlorophyll b, total chlorophyll (mg.g ${ }^{-1}$ fresh weight of leaf) was measured by extracting fresh leaves which were added with $80 \%$ of acetone, then the resulting filtrate was measured using a $2 \mathrm{D}$ Milton Roy Spectrophotometer at a wavelength of $663 \mathrm{~nm}$ and $645 \mathrm{~nm}$. Nitrate reductase activity $(\mu \mathrm{mol}$ $\mathrm{NO}_{2}{ }^{-} \cdot \mathrm{g}^{-1} \cdot$ hour ${ }^{-1}$ ) was measured by extracting leaves which were added with phosphate buffer and $\mathrm{NaNO}_{3}$ solution, then the filtrate produced was measured using a 2 D Milton Roy Spectrophotometer at a wavelength of $540 \mathrm{~nm}$. Proline content $\left(\mu \mathrm{mol.g} \mathrm{g}^{-1}\right.$ fresh weight of leaf) was calculated by extracting leaves which were added with $3 \%$ of sulfosalicylic acid, ninhydrin acid, and $100 \%$ of glacial acetic acid, then the resulting filtrate was measured using a Spectro 2 D Milton Roy Spectrophotometer at a wavelength of $520 \mathrm{~nm}$. Observation of chlorophyll content, nitrate reductase activity, and proline content was carried out when plants were 7 weeks after planting. Concentration of leaf $\mathrm{Na}^{+}$and $\mathrm{K}^{+}\left(\mathrm{mmol} . \mathrm{g}^{-1}\right.$ dry weight of sample leaf) was measured by extracting leaves added with $\mathrm{HNO}_{3}{ }^{-}$solution, then the filtrate obtained was measured using the PFP7 Flame Photometer. Observation of leaf $\mathrm{Na}^{+}$and $\mathrm{K}^{+}$concentrations was done when plants were 3 weeks after planting, 6 weeks after planting, and at harvest time. Plant height $(\mathrm{cm})$ was measured using a meter from the base of the stem to the highest end of the leaf and the number of tillers that grew; observing both parameters was done when plants were 8 weeks after planting. Canopy dry weight $\left(\right.$ g.clump $\left.^{-1}\right)$, root dry weight (g.clump ${ }^{-1}$ ), and biomass $\left(\right.$ g.clump $\left.^{-1}\right)$ used digital scales when harvested. Number of panicles per clump, panicle length $(\mathrm{cm})$, percentage of filled grain (\%), weight of 1,000 grain (g), grain weight per clump (g.clump ${ }^{-1}$ ), grain weight per plot (g.plot $\left.{ }^{-1}\right)$, and harvest index were observed after plants were harvested.

Variance analysis (ANOVA) was used to analyze data. When a significant effect was obtained, the analysis was continued by using the Duncan's multiple range test at $5 \%$ error level. Processing statistical data analysis was carried out using SAS 9.1.3 Portable software.

\section{RESULTS AND DISCUSSION}

\section{Soil and water conditions in research area}

The soil analysis was carried out in STIPER Agriculture Institute Yogyakarta (2017). It showed that before and after harvesting, the soil was indicated in neutral $\mathrm{pH}$ which ranged between 6.57 and 6.88 . Soil moisture contents of $0.5 \mathrm{~mm}$ deep before planting was $11.35 \%$, and after harvest in the raised-bed and sunken-bed of $25 \mathrm{~cm}$ and $50 \mathrm{~cm}$ depth were $6.03 \%$, $9.54 \%$, and $9.01 \%$, respectively. The total $\mathrm{N}$ contents in the soil before planting was $0.19 \%$, and after harvest in raised-bed and sunken-bed of $25 \mathrm{~cm}$ and $50 \mathrm{~cm}$ depth were $0.13 \%, 0.16 \%$, and $0.15 \%$ respectively. The content of $\mathrm{Na}^{+}$in the soil before planting was $0.13 \mathrm{me} .100 \mathrm{~g}^{-1}$, and after harvest in sunken-beds of the $25 \mathrm{~cm}$ and $50 \mathrm{~cm}$ of depths were $0.11 \mathrm{me} .100 \mathrm{~g}^{-1}$,

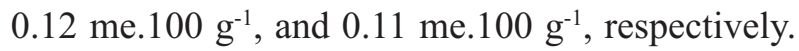
The content of $\mathrm{K}^{+}$in the soil before planting was $0.21 \mathrm{me} .100 \mathrm{~g}^{-1}$, and after harvest in raised-bed and sunken-bed of 25 and $50 \mathrm{~cm}$ of depth were 0.20 me. $100 \mathrm{~g}^{-1}, 0.19 \mathrm{me} .100 \mathrm{~g}^{-1}$, and $0.18 \mathrm{me} .100 \mathrm{~g}^{-1}$, respectively. The content of $\mathrm{Ca}_{2}{ }^{+}$in the soil before planting was 8.17 me.100 $\mathrm{g}^{-1}$, and after harvest in raised-bed and sunken-bed with $25 \mathrm{~cm}$ and $50 \mathrm{~cm}$ of depth were 11.26 me.100 g $\mathrm{g}^{-1}, 9.47 \mathrm{me}^{100 \mathrm{~g}^{-1} \text {, and }}$ $6.55 \mathrm{me} .100 \mathrm{~g} \mathrm{~g}^{-1}$. The content of $\mathrm{Mg}_{2}{ }^{+}$in the soil before planting was 1.04 me. $100 \mathrm{~g} \mathrm{~g}^{-1}$, in the soil after harvest in raised-bed and sunken-bed with $25 \mathrm{~cm}$ and $50 \mathrm{~cm}$ of depth, were $0.91 \mathrm{me} .100 \mathrm{~g}^{-1}, 1.31$ me. $100 \mathrm{~g}^{-1}$, and 0.78 me. $100 \mathrm{~g}^{-1}$, respectively.

The EC value of irrigation water in the command area ranged from 1.07-25 dS.m ${ }^{-1}$ (Figure 1). According 


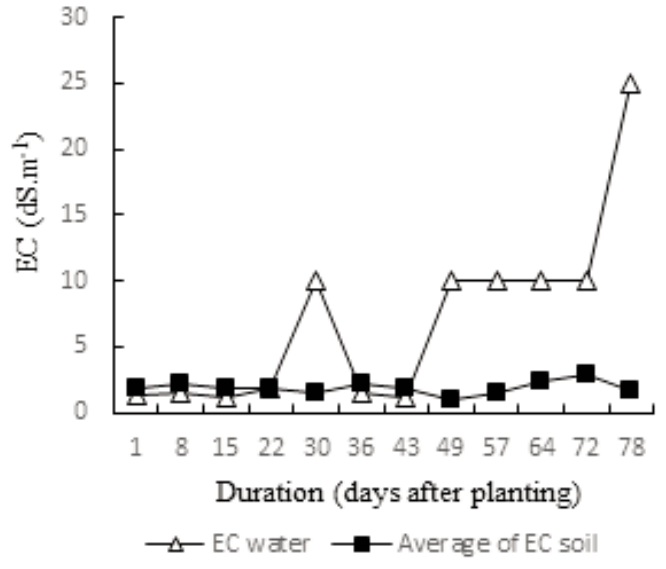

Figure 1. The electrical conductivity of water and soil in the command area

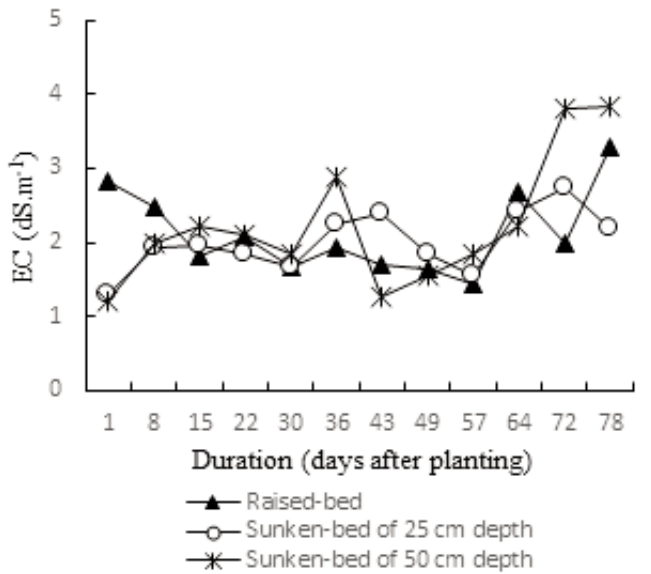

Figure 2. The electrical conductivity of raised-bed soil and sunken-bed soil with $25 \mathrm{~cm}$ and $50 \mathrm{~cm}$ of depths

Table 1. Leaf area of 3 and 6 weeks after planting $\left(\mathrm{cm}^{2}\right.$. clump $\left.{ }^{-1}\right)$, photosynthesis rate of 6 weeks after planting ( $\mu$ mol $\left.\mathrm{CO}_{2} \cdot \mathrm{m}^{-2} \cdot \mathrm{s}^{-1}\right)$, and chlorophyll content in the leaf of 7 weeks after planting ( $\mathrm{mg} \cdot \mathrm{g}^{-1}$ fresh weight of leaf) plant of Inpari 29 rice variety grown on raised-beds and different depths of sunken-beds

\begin{tabular}{|c|c|c|c|c|c|c|}
\hline \multirow{2}{*}{ Treatment } & \multicolumn{2}{|c|}{ Leaf area $\left(\mathrm{cm}^{2}\right)$} & \multirow{2}{*}{$\begin{array}{c}\text { Photosynthesis } \\
\text { rate }(\mu \mathrm{mol} \\
\left.\mathrm{CO}^{2} \cdot \mathrm{m}^{-2} \cdot \mathrm{s}^{-1}\right)\end{array}$} & \multicolumn{3}{|c|}{$\begin{array}{l}\text { Chlorophyll content in the leaf } \\
\text { (mg.g }{ }^{-1} \text { fresh weight of leaf) }\end{array}$} \\
\hline & 3 wap & 6 wap & & Chlorophyll a & Chlorophyll b & Chlorohyll total \\
\hline \multicolumn{7}{|l|}{$\overline{\text { Depth }}$} \\
\hline $50 \mathrm{~cm}$ & $192.80 \mathrm{a}$ & $450.92 \mathrm{a}$ & $9.22 \mathrm{a}$ & $19.58 \mathrm{a}$ & $19.12 \mathrm{a}$ & $38.69 \mathrm{a}$ \\
\hline $25 \mathrm{~cm}$ & $219.65 \mathrm{a}$ & $567.26 \mathrm{a}$ & $10.82 \mathrm{a}$ & $20.27 \mathrm{a}$ & $19.81 \mathrm{a}$ & $40.07 \mathrm{a}$ \\
\hline \multicolumn{7}{|l|}{ Planting Area } \\
\hline Raised-bed & $187.89 \mathrm{p}$ & $480.61 \mathrm{p}$ & $9.13 \mathrm{p}$ & $15.58 \mathrm{q}$ & $11.79 \mathrm{q}$ & $27.36 \mathrm{q}$ \\
\hline Sunken-bed & $224.56 \mathrm{p}$ & $537.57 \mathrm{p}$ & $10.91 \mathrm{p}$ & $24.28 \mathrm{p}$ & $27.14 p$ & $51.41 \mathrm{p}$ \\
\hline Interaction & - & - & - & - & - & - \\
\hline $\mathrm{CV}(\%)$ & 10.05 & 20.23 & 14.41 & $14.87 *$ & $28.98 *$ & $21.98 *$ \\
\hline
\end{tabular}

Note: (-) no interaction; wap (weeks after planting); $(*)$ the data was transformed; the number followed by the same letter in the same column has no significant different in the Duncan's Multiple Range Test at 5\% error level

to the Soil Research Center (2009), based on the assessment criteria, EC $>4 \mathrm{dS} . \mathrm{m}^{-1}$ was considered very high. The EC value of raised-bed and sunken-bed with $25 \mathrm{~cm}$ and $50 \mathrm{~cm}$ depth were 2.22, 2.02, and $2.36 \mathrm{dS} . \mathrm{m}^{-1}$, respectively (Figure 2). Based on the EC value, referring to the classification of dissolved saline in the soil, the EC value of the soil was classified rather saline.

\section{Leaf area, chlorophyll content in the leaf and photosynthesis rate}

Leaf is the main component of plants functioning as a place for photosynthesis. It is increasingly widespread and has the ability to hold more and more light (Syamsuddin et al., 2011). Table 1 shows that the leaf area and photosynthetic rate of the rice plant were not significantly different between planting area and depth treatments. It was assumed that the plant had the same adaptability in both treatments which had no different soil and water electro conductivity (Figure 1) so that the leaf area and photosynthesis rate of plants were not different.

Chlorophyll is mostly found in leaves. It is the green leaves that play a role of the photosynthesis process (Hussain et al., 2017.) Table 1 shows that the rice planted in sunken-bed contained higher chlorophyll a, chlorophyll $\mathrm{b}$, and total chlorophyll than in raised-bed. The high content of chlorophyll in rice grown in sunken-bed due to the adequate availability of water, soil $\mathrm{N}$ content, and soil $\mathrm{Mg}_{2}{ }^{+}$ content. Rice planted in raised-bed has limited water. Limited water affects cell turgor, thus reducing cell development, inhibiting protein synthesis, chlorophyll and cell walls (Ai and Banyo, 2011). Chlorophyll synthesis was affected by several factors including light, sugar or carbohydrates, water, temperature, plant genetic factors, and some elements such as $\mathrm{N}$ and $\mathrm{Mg}_{2}{ }^{+}$. Gohagu et al. (2016) detailed that $\mathrm{N}$ had the role in the production of chlorophyll and the element $\mathrm{Mg}_{2}{ }^{+}$was the core of chlorophyll. 
Table 2. Leaf $\mathrm{Na}^{+}$and $\mathrm{K}^{+}$concentration (mmol.g-1 dry weight of sample leaf) in Inpari 29 rice variety at 3 weeks after planting, 6 weeks after planting, and when harvested grown on raised-beds and different depths of sunken-beds

\begin{tabular}{|c|c|c|c|c|c|c|}
\hline \multirow[t]{2}{*}{ Treatment } & \multicolumn{3}{|c|}{$\begin{array}{l}\text { Leaf } \mathrm{Na}^{+} \text {concentration(mmol.g }{ }^{-1} \text { dry weight of } \\
\text { sample leaf) }\end{array}$} & \multicolumn{3}{|c|}{$\begin{array}{c}\text { Leaf } \mathrm{K}^{+} \text {concentration } \\
\text { (mmol.g }{ }^{-1} \text { dry weight of sample leaf) }\end{array}$} \\
\hline & 3 wap & 6 wap & When harvested & 3 wap & 6 wap & When harvested \\
\hline \multicolumn{7}{|l|}{ Depth } \\
\hline $50 \mathrm{~cm}$ & $19.8 \mathrm{a}$ & $26.4 \mathrm{a}$ & $39.2 \mathrm{a}$ & $28.5 \mathrm{a}$ & $28.8 \mathrm{a}$ & $24.6 \mathrm{a}$ \\
\hline $25 \mathrm{~cm}$ & $22 \mathrm{a}$ & $20.6 \mathrm{a}$ & $34 \mathrm{a}$ & $27 \mathrm{a}$ & $24.9 \mathrm{a}$ & $26.7 \mathrm{a}$ \\
\hline \multicolumn{7}{|l|}{ Planting Area } \\
\hline Raised-bed & $14.3 \mathrm{q}$ & $17.9 \mathrm{q}$ & $29.1 \mathrm{p}$ & $27.5 \mathrm{p}$ & $30.7 \mathrm{p}$ & $25.2 \mathrm{p}$ \\
\hline Sunken-bed & $27.5 \mathrm{p}$ & $29.1 \mathrm{p}$ & $44.1 \mathrm{p}$ & $27.9 \mathrm{p}$ & $22.9 \mathrm{q}$ & $26.1 \mathrm{p}$ \\
\hline Interaction & - & - & - & - & - & - \\
\hline$\overline{C V}(\%)$ & $14.41 *$ & $20.52 *$ & 21.08 & 5.49 & 27.70 & 22.31 \\
\hline
\end{tabular}

Note: (-) no interaction; wap (weeks after planting); $(*)$ the data was transformed; the number followed by the same letter in the same column has no significant different in the Duncan's Multiple Range Test at 5\% error level

Treatment of $50 \mathrm{~cm}$ and $25 \mathrm{~cm}$ of depths did not give significant difference on the leaf chlorophyll content (Table 2) because both conditions had the same water availability with fluctuating salts concentration and not significantly different from total $\mathrm{N}$ content. Water availability could help the distribution of nutrients and played important role in the photosynthesis process, whereas the $\mathrm{N}$ content was needed by plants for chlorophyll synthesis.

\section{Concentration of $\mathrm{Na}^{+}$and $\mathrm{K}^{+}$ions on leaves, reductase nitrate activity, and proline content}

The purpose of $\mathrm{Na}^{+}$analysis in tissues was to determine the concentration of $\mathrm{Na}^{+}$ions in the leaves absorbed by the plants. The amount of $\mathrm{Na}^{+}$ions absorbed by plant tissues showed the possibility of plants caught in salinity. $\mathrm{Na}^{+}$acted as a nitrate reductase regulator, stomatal opening, and amino acid citase such as proline and betaine.

Table 2 shows that the concentration of $\mathrm{Na}^{+}$ions in the leaves of aged 3 and 6 weeks after planting rice planted in sunken-bed was higher than in raised-bed. The concentration of $\mathrm{Na}^{+}$ions in the leaves was affected by the amount of EC in the soil and irrigation water. When plants were 3 and 6 weeks after planting, irrigation water EC was \pm 2.5 $\mathrm{dS} . \mathrm{m}-1$ with soil EC ranging from $2-2.5 \mathrm{dS} . \mathrm{m}^{-1}$. The value of EC illustrated that the condition of irrigation water and soil contained salt. The accumulation of salt in the sunken-bed soil was larger than in the raised-bed (Figure 2). Plants exposed to a combined salinity and submergence was reported to increase $\mathrm{Na}^{+}$transport to the shoots than saline aerated roots (Kurniasih et al., 2017). Salt accumulation caused the plant to become gripped with salinity. This was indicated by the increasing of $\mathrm{Na}^{+}$ions concentration in the leaves 3 and 6 weeks after planting. Large amount of $\mathrm{Na}^{+}$in the soil would enter the root area and cause more $\mathrm{Na}^{+}$ions to be absorbed by the plants than other elements. When the plant was gripped with salinity, the presence of $\mathrm{Na}^{+}$ions concentration would be inversely proportional to the $\mathrm{K}^{+}$ions concentration. Increased absorption of $\mathrm{Na}^{+}$ions in the plants caused high accumulation of $\mathrm{Na}^{+}$ions in the plant tissues. In such conditions, there would be obstacles for the roots to absorb other elements such as $\mathrm{K}^{+}, \mathrm{Ca}_{2}{ }^{+}$, and $\mathrm{Mg}_{2}{ }^{+}$(Mass and Hoffman, 1997). Munns and Tester (2008) stated that salinity caused plants to experience osmotic stress and ionic stress. These stresses caused water absorption and nutrients other than $\mathrm{Na}^{+}$ions to be inhibited due to the higher osmotic potential in the cell than the osmotic potential outside the cell. Rice planted in $25 \mathrm{~cm}$ and $50 \mathrm{~cm}$ of depths showed a concentration of $\mathrm{Na}^{+}$ions in the leaves that were not significantly different (Table 2). This is presumably due to the depth treatment, EC of water and soil have a value that is not different so that it affects the plant within the same limit.

The element of $\mathrm{K}$ was absorbed by the plants in the form of $\mathrm{K}^{+}$ions. The results showed that in general, the concentration of $\mathrm{K}^{+}$ions in leaves would be decreased in line with increasing concentration of $\mathrm{Na}^{+}$ions. Increased concentration of $\mathrm{Na}^{+}$ion in leaves 6 weeks after planting would decrease $\mathrm{K}^{+}$ions concentration (Table 2) in sunken-bed planting treatment. Such condition was because $\mathrm{Na}^{+}$and $\mathrm{K}^{+}$ nutrients indicated very similar properties that were mutually inhibiting (Yoshiva and Casteneda, 1969). Therefore, when the $\mathrm{Na}^{+}$content was higher, it would be difficult for the plant to absorb $\mathrm{K}^{+}$and vice versa. 
Table 3. Nitrate reducates activity $\left(\mu \mathrm{mol} \mathrm{NO}{ }^{-} \cdot \mathrm{g}^{-1}\right.$.hour $\left.{ }^{-1}\right)$ at 7 weeks after planting of Inpari 29 rice variety grown on raised-beds and different depths of sunken-beds

\begin{tabular}{lccc}
\hline \multirow{2}{*}{ Treatment } & \multicolumn{2}{c}{ Reductase nitrate activity $\left(\mu \mathrm{mol} \mathrm{NO}_{2}{ }^{-} \cdot \mathrm{g}^{-1} \cdot\right.$ hour $\left.^{-1}\right)$} \\
\cline { 2 - 3 } & $50 \mathrm{~cm}$ & Depth & Average \\
\cline { 2 - 3 } & & $25 \mathrm{~cm}$ & 0.16 \\
Planting Area & $0.27 \mathrm{~b}$ & $0.05 \mathrm{c}$ & 0.52 \\
Raised-bed & $0.10 \mathrm{c}$ & $0.94 \mathrm{a}$ & $0.34(+)$ \\
Sunken-bed & 0.19 & 0.50 & \\
\hline Average & & 15.28 & \\
\hline $\mathrm{CV}(\%)$ & & & \\
\hline
\end{tabular}

Note: $(+)$ there is interaction; the number followed by the same letter in the same column is not significantly different in Duncan's Multiple Range Test at 5\% error level

Table 4. Prolin content ( $\mu \mathrm{mol} . \mathrm{g}^{-1}$ fresh weight of leaf) at 7 weeks after planting of Inpari 29 rice variety grown on raised-beds and different depths of sunken-beds

\begin{tabular}{lccc}
\hline \multirow{2}{*}{ Treatment } & \multicolumn{2}{c}{ Proline content $\left(\mu \mathrm{mol} \cdot \mathrm{g}^{-1}\right.$ fresh weight of leaf $)$} \\
\cline { 2 - 3 } & $50 \mathrm{~cm}$ & Depth & Average \\
\cline { 2 - 3 } & & $25 \mathrm{~cm}$ & \\
\hline Planting Area & $3.02 \mathrm{a}$ & $0.66 \mathrm{~b}$ & 1.84 \\
Raised-bed & $0.77 \mathrm{~b}$ & $0.93 \mathrm{~b}$ & 0.85 \\
Sunken-bed & 1.90 & 0.79 & $1.34(+)$ \\
\hline Average & & 18.97 & \\
\hline CV $(\%)$ & Note: $(+)$ there is interaction; the number followed by the same letter in the same column is not
\end{tabular}
significantly different in Duncan's Multiple Range Test at 5\% error level

Nitrate reductase is an important enzyme in the reduction of chain of $\mathrm{NO}_{3}{ }^{-}$to $\mathrm{NO}_{2}{ }^{-}$, then $\mathrm{NO}_{2}{ }^{-}$will experience anomification with the help of nitrite reductase (NiR) enzyme and $\mathrm{NH}_{4}{ }^{+}$will be converted into free nitrogen gas with the help of nitrogenize enzyme. Nitrate reductase enzymes are useful in the formation of amino acids, chlorophyll, and other compounds that contain N (Peni et al., 2004). Table 3 shows that raised-bed with $50 \mathrm{~cm}$ of height indicated greater nitrate reductase activity value compared to the one with $25 \mathrm{~cm}$ of height. The raised-bed with $25 \mathrm{~cm}$ of height showed greater nitrate reductase activity value than in sunken-bed treatment with 25 $\mathrm{cm}$ of depth. The raised-bed treatment which was 50 $\mathrm{cm}$ high showed greater nitrate reductase activity value compared to sunken-bed which was $50 \mathrm{~cm}$ deep. In sunken-bed with $25 \mathrm{~cm}$ of depth, the nitrate reductase activity value was greater than in raised-bed treatment with $25 \mathrm{~cm}$ of height. Such result was due to the concentration of $\mathrm{Na}^{+}$ions that had not been toxic for the plant when observed. According to Muflikhah (2018), $\mathrm{Na}^{+}$ions at certain concentrations can function as osmotic regulators and are able to carry out cytoplasmic functions by replacing $\mathrm{K}^{+}$ions in binding Mo. This prevented nitrate reduktase activity from disturbance and caused the plant to synthesize chlorophyll in the vegetative phase.

Proline is one of the amino acids produced by plants when they experience salinity stress (Tatar $e t$ al., 2010). Table 4 shows that raised-bed with $50 \mathrm{~cm}$ of height provided the highest proline content compared to other treatments. It was expected that rice plants in raised-bed with $50 \mathrm{~cm}$ of height underwent salinity stress due to the accumulation of salt deposited in the soil from irrigation water with fluctuating EC. Fluctuating salt accumulation in the soil due to irrigation water with EC (Figure 1) allowed it to become toxic to plants. The plants produced proline due to salinity stress through cell osmotic balance. When the plant was gripped with salinity, the osmotic potential in the cell got higher than the osmotic potential outside the cell. The high osmotic potential in the cell caused the absorption of water and minerals to become inhibited. This would spur the plants to adapt by increasing their resistance and inducing the accumulation of amino acids in the cytoplasm, prolin (Munns and Tester, 2008). Proline production and accumulation were adaptive forms of plants in response to salinity stress (Gupta et al., 2014). Proline increased along with the decreasing of osmotic 
Table 5. Plant height $(\mathrm{cm})$ and number of total tiller at 8 weeks after planting, and canopy dry weight $\left(\mathrm{g} . \mathrm{clump}^{-1}\right)$, root dry weight $\left(\right.$ g.clump $\left.{ }^{-1}\right)$, and total biomass $\left(\right.$ g.clump $\left.{ }^{-1}\right)$ when harvested in Inpari 29 rice variety grown on raisedbeds and different depths of sunken-beds

\begin{tabular}{|c|c|c|c|c|c|}
\hline Treatments & $\begin{array}{c}\text { Plant Height }(\mathrm{cm}) \\
8 \text { wap }\end{array}$ & $\begin{array}{l}\text { Number of total } \\
\text { tiller at } 8 \text { wap }\end{array}$ & $\begin{array}{c}\text { Canopy dry weight } \\
\text { (g.clump }^{-1} \text { ) when } \\
\text { harvested }\end{array}$ & $\begin{array}{l}\text { Root dry weight } \\
\left(\text { g.clump }{ }^{-1} \text { ) when }\right. \\
\text { harvested }\end{array}$ & $\begin{array}{c}\text { Total biomass } \\
(\text { g.clump } \\
\text { harvested }\end{array}$ \\
\hline \multicolumn{6}{|l|}{ Depth } \\
\hline $50 \mathrm{~cm}$ & $91.62 \mathrm{a}$ & $13.58 \mathrm{a}$ & $21.21 \mathrm{a}$ & $12.97 \mathrm{a}$ & $33.57 \mathrm{a}$ \\
\hline $25 \mathrm{~cm}$ & $91.35 \mathrm{a}$ & $15.33 \mathrm{a}$ & $23.10 \mathrm{a}$ & $9.73 \mathrm{a}$ & $32.69 \mathrm{a}$ \\
\hline \multicolumn{6}{|l|}{ Planting Area } \\
\hline Raised-bed & $81.27 \mathrm{q}$ & $15.75 \mathrm{p}$ & $22.48 p$ & $14.45 \mathrm{p}$ & $36.58 \mathrm{p}$ \\
\hline Sunken-bed & $101.7 \mathrm{p}$ & $13.17 \mathrm{q}$ & $21.83 \mathrm{p}$ & $7.82 \mathrm{q}$ & $29.69 p$ \\
\hline Interaction & - & - & - & - & - \\
\hline$\overline{\mathrm{CV}(\%)}$ & 6.09 & 16.49 & 24.93 & 29.20 & 15.36 \\
\hline
\end{tabular}

Note: (-) no interaction; wap (weeks after planting); $\left({ }^{*}\right)$ the data was transformed; the number followed by the same letter in the same column has no significant different in the Duncan's Multiple Range Test at 5\% error level

potential in cells. The decrease in osmotic potential in cells caused plants to maintain cell turgor so that the physiological and biochemical processes continue to run even under drought stress conditions (Kurniawati et al., 2014; Guo et al., 2012).

\section{Plant height, number of tillers, canopy dry weight, root dry weight, and biomass}

Plant height is an indicator of plant growth as well as the parameter used to measure plant growth due to a given treatment. Table 5 shows that in 8 weeks after planting, rice planted in sunken-bed was taller than in raised-bed. Allegedly, such result was due to more water availability supporting the plant growth by maintaining cell turgidity and helping the cell growth. In addition, it was also because of the fluctuating plant resistance to irrigation water with EC ranged from 1.07-25 dS.m ${ }^{-1}$, and that rice plants planted in sunken-bed were positioned below and flanked by rice plants. The plants in raised-bed put efforts to look for light used for their photosynthetic material. Thus, in such conditions, the plant became taller.

Table 5 shows that the rice planted in raised-bed in 8 weeks after planting had a greater number of total tillers compared to rice in sunken-bed, although it was not significantly different in both depth treatment. Such a small number of tillers from rice planted in sunken-bed was thought to be due to waterlogging conditions that could suppress their growth. This is consistent with the statements from Zheng (2005); Rivaldi (2015) that waterlogging can inhibit the growth rate of tillers. Waterlogging causes lack of airspace for tillers to surface due to water pressure (Ikhwani et al., 2010). Rice planted in 25 $\mathrm{cm}$ and $50 \mathrm{~cm}$ of depths resulted in number of total tillers that were not different because both treatments were affected by the water availability which waterlogged the plants.

Depth and planting area treatments resulted in no different canopy dry weight (Table 5). This was because rice planted in raised-bed and sunken-bed with $25 \mathrm{~cm}$ and $50 \mathrm{~cm}$ of depths had a different rate of photosynthesis (Table 1). On account of the same photosynthesis rate, photosynthate produced in both treatments were also the same. The photosynthate produced would be buried in both vegetative and generative organs of plants. Photosynthate was translocated at the same amount in the vegetative organs of the plants in each treatment so as to produce dry canopy weight that was not different between treatments.

Rice was grown in raised-bed showed greater root dry weight than in sunken-bed (Table 5). Allegedly, by reason of limited water availability, the roots of rice planted in raised-bed would try to reach water and nutrients in the soil and experience expansion. Muis et al. (2013) stated that when water is lacking, plants will withstand its canopy growth rate and increase its root growth rate. This aims to prevent the amount of water loss, because the root growth rate requires less water than the canopy growth rate that will enlarge the respiration process through formation of the leaf. A higher root growth rate in raised-bed planting resulted in more considerable root dry weight than in sunken-bed.

Table 5 shows the biomass of plants when harvested that was not significantly different between planting field and depth treatments because they did not indicate different photosynthesis rate. The photosynthesis 
Table 6. Number of panicles per clump, panicle length $(\mathrm{cm})$, percentage of filled seeds (\%), weight of 1,000 grains (g), and harvest index of Inpari 29 variety grown on raised-bed and different depths of sunken-beds

\begin{tabular}{lccccc}
\hline Treatments & $\begin{array}{c}\text { Number of pani- } \\
\text { cles per clump }\end{array}$ & $\begin{array}{c}\text { Panicle length } \\
(\mathrm{cm})\end{array}$ & $\begin{array}{c}\text { Filled grain } \\
(\%)\end{array}$ & $\begin{array}{c}\text { Weight of 1,000 } \\
\text { grains }(\mathrm{g})\end{array}$ & $\begin{array}{c}\text { Harvest } \\
\text { index }\end{array}$ \\
\hline Depth & $11.67 \mathrm{a}$ & $24.98 \mathrm{a}$ & $60.05 \mathrm{a}$ & $16.67 \mathrm{a}$ & $0.26 \mathrm{a}$ \\
$50 \mathrm{~cm}$ & $12.00 \mathrm{a}$ & $22.42 \mathrm{a}$ & $62.18 \mathrm{a}$ & $17.07 \mathrm{a}$ & $0.32 \mathrm{a}$ \\
$25 \mathrm{~cm}$ & & & & $16.33 \mathrm{p}$ & $0.10 \mathrm{q}$ \\
\hline Planting Area & $12.83 \mathrm{p}$ & $23.71 \mathrm{p}$ & $59.88 \mathrm{p}$ & $17.40 \mathrm{p}$ & $0.40 \mathrm{p}$ \\
Raised-bed & $10.83 \mathrm{p}$ & $23.69 \mathrm{p}$ & $62.35 \mathrm{p}$ & - & - \\
Sunken-bed & - & - & - & 7.48 & $8.82^{*}$ \\
\hline Interaction & 6.45 & 12.19 & 12.78 & - & \\
\hline CV $(\%)$ & & & & & \\
\hline
\end{tabular}

Note: (-) no interaction; wap (weeks after planting); $(*)$ the data was transformed; the number followed by the same letter in the same column has no significant different in the Duncan's Multiple Range Test at 5\% error level

rate would produce photosynthate before being translocated to vegetative and generative organs of the plant. Photosynthates translocated to the vegetative part of the plant, i.e., the canopy, did not show any significant differences. Albeit not different, the rice planted in raised-bed showed higher biomass because it performed higher rate of root growth than the canopy. Rice planted in $25 \mathrm{~cm}$ and $50 \mathrm{~cm}$ of depths showed biomass of plants that were not different due to the same water availability. Such water availability in-depth treatment helped the plant roots to absorb nutrients. According to Lakitan (1993), nutrients absorbed by plants through the roots would contribute to the addition of plant weight.

\section{Yield Components}

Table 6 shows that the number of panicles per clump, panicle length, percentage of filled grain, and 1,000 grain weight were not significantly different between planting area and depth treatments. Growth of the number of panicles per clump indicated the number of productive tillers of rice plants. According to Sutaryo (2012), a number of panicles per clump illustrated the number of productive tillers and the large number of panicles per clump that could increase grain yield. Table 6 shows that the number of panicles per clump was not different between planting area and depth treatments due to the same source of sink distribution. Panicle length and 1,000 grain weight were not significantly different between the two treatments owing to the same variety of the planted rice. The genetic nature of the variety affected the two variables. The percentage of filled grain was not significantly different between the two treatments by reason of the generative phase; water EC that reached 10-25 dS.m ${ }^{-1}$ with soil EC between 2.5-3
dS.m ${ }^{-1}$. Waterlogging and submergence with almost the same EC in raised-bed and sunken-bed with 25 $\mathrm{cm}$ and $50 \mathrm{~cm}$ of depths caused no different percentage of filled grain. Such conditions could become abiotic stresses for plants and lead to fertilization failure and low translocation of photosynthate to become grain.

The harvest index is the ratio of grain weight to the total biomass as the parameter that describes the distribution of photosynthate. Table 6 shows that rice planted in sunken-bed indicated higher harvest index than in raised-bed. This was due to the higher dry weight of grain and lower plant biomass compared to rice plants grown in raised-bed (Table 6). Tubur et al. (2012) stated that increasing the value of the harvest index will increase the yield of grain.

Table 7 and Table 8 shows that rice planted in sunken-bed with $25 \mathrm{~cm}$ of depth resulted in higher grain weight per clump and grain weight per plot than that with $50 \mathrm{~cm}$ of depth. When planted in raised-bed with $50 \mathrm{~cm}$ and $25 \mathrm{~cm}$ of height, it produced the same grain weight per clump and grain weight per plot. When planted in sunken-bed with $25 \mathrm{~cm}$ of depth, it resulted in higher grain weight per clump and grain weight per plot than in raised-bed with 25 $\mathrm{cm}$ of height. Rice planted in sunken-bed of $50 \mathrm{~cm}$ resulted in higher grain weight per clump and grain weight per plot than in raised-bed of $50 \mathrm{~cm}$.

Grain weight per clump and grain weight per plot was greater in the sunken-bed treatment with $25 \mathrm{~cm}$ and $50 \mathrm{~cm}$ of depths compared to the raised-bed treatment with $25 \mathrm{~cm}$ and $50 \mathrm{~cm}$ of height because the first treatment resulted in more panicles per clump and more significant percentage of grain content although it was not significantly different (Table 6). The photosynthate result was sufficient for panicle and seed formation. Limited water given to the 
Table 7. Grain weight per clump (g) of Inpari 29 rice variety grown on raised-beds and different depths of sunken-beds

\begin{tabular}{|c|c|c|c|}
\hline \multirow{3}{*}{ Treatment } & \multicolumn{3}{|c|}{ Grain weight per clump (g) } \\
\hline & \multicolumn{2}{|c|}{ Depth } & \multirow{2}{*}{ Average } \\
\hline & $50 \mathrm{~cm}$ & $25 \mathrm{~cm}$ & \\
\hline \multicolumn{4}{|l|}{ Planting Area } \\
\hline Raised-bed & $7.18 \mathrm{c}$ & $6.62 \mathrm{c}$ & 6.90 \\
\hline Sunken-bed & $9.53 \mathrm{~b}$ & $12.82 \mathrm{a}$ & 11.17 \\
\hline Average & 8.36 & 9.77 & $9.04(+)$ \\
\hline$\overline{\mathrm{CV}(\%)}$ & & 3.66 & \\
\hline
\end{tabular}
significantly different in Duncan's Multiple Range Test at 5\% error level

Table 8. Grain weight per plot (g) of Inpari 29 rice variety grown on raised-beds and different depths of sunken-beds

\begin{tabular}{|c|c|c|c|}
\hline \multirow{3}{*}{ Treatment } & \multicolumn{3}{|c|}{ Grain weight per plot (g) } \\
\hline & \multicolumn{2}{|c|}{ Depth } & \multirow{2}{*}{ Average } \\
\hline & $50 \mathrm{~cm}$ & $25 \mathrm{~cm}$ & \\
\hline \multicolumn{4}{|l|}{ Planting Area } \\
\hline Raised-bed & $278 \mathrm{c}$ & $252 \mathrm{c}$ & 265 \\
\hline Sunken-bed & $366 \mathrm{~b}$ & $492 \mathrm{a}$ & 429 \\
\hline Average & 322 & 372 & $347(+)$ \\
\hline$\overline{\mathrm{CV}(\%)}$ & & 3.90 & \\
\hline
\end{tabular}

rice planted in raised-bed caused lower photosynthate produced because the rate of root growth was higher than biomass. Such result was found in plants that were unable to utilize photosynthate for their panicle and seed formation optimally. The sunken-bed treatment with $25 \mathrm{~cm}$ of depth resulted in larger grain weight per clump than of $50 \mathrm{~cm}$ depth because when the seeds experienced maturation, it required only small amount of water.

Waterlogging on saline field increased grain weight per clump owing to the fact that the canopy of waterlogged rice plant experienced faster growth than the root. The canopy growth rate supported the photosynthesis process which would produce photosynthates that were useful for seed formation, even in small amount. Different depths resulted in significant differences in growth and yield variables. Nevertheless, during the process of seed maturation, less water was needed which led to a higher percentage of filled grain in $25 \mathrm{~cm}$ of depth treatment although it was not significant.

\section{CONCLUSIONS}

Compared to raised-bed treatment, sunken-bed treatment gave better rice growth. This was indicated by the higher content of chlorophyll a, chlorophyll b, total chlorophyll, nitrate reductase activity, and plants height. It also yielded better results than raised-bed treatment as shown by higher harvest index and grain weight per clump. Meanwhile, rice planted in sunken-bed with $25 \mathrm{~cm}$ of depth showed a higher value of nitrate reductase activity, grain weight per clump, and grain weight per plot than that with $50 \mathrm{~cm}$ of depth.

\section{ACKNOWLEDGEMENT}

The authors gratefully acknowledge from The Ministry of Research and Technology Higher Education Republic of Indonesia for funding this research.

\section{REFERENCES}

Ai, N.S. and Y. Banyo. 2011. Konsentrasi klorofil daun sebagai indikator kekurangan air pada tanaman. Jurnal ilmiah sains., 11: 166-173. 
Aref, F. 2013. Effect of saline irrigation water on yield and yield components of rice (Oryza sativa L.). African Journal of Biotechnology., 12: 3503-3513.

Balai Penelitian Tanah. 2009. Analisis kimia tanah, tanaman, air, dan pupuk. Bogor: Balai Penelitian dan Pengembangan Pertanian, Departemen Pertanian.

BB Padi. 2012. Deskripsi padi varietas inpari 29. http://bbpadi.litbang.pertanian.go.id/index.p $\mathrm{hp} /$ varietas/inbrida-padi-sawah-irigasi-inpari/content/item/32-inpari-29-rendaman.

Bruins, R.J.F., C. Shuming., C. Shijian and W.J. Mitsch. 2012. Ecological engineering strategies to reduce flooding damage to wetland crops in central China. Ecological Engineering., 11:231-259.

Cha-um, S. and C. Kirdmanee. 2010. Effect of Glycine betaine on Proline, Water Use, and Photosynthetic Efficiencies, and Growth of Rice Seedlings Under Salt Stress. Turk Journal Agricultural Forestry., 34:517-527.

Ella, E. S., N. Kawano and O. Ito. 2003. Importance of active oxygen scavenging system in the recovery of rice seedlings after submergence. Plant Science Journal., 165:85-93.

FAO. 2005. 20 Hal untuk diketahui tentang dampak air laut pada lahan di provinsi NAD. http://www.fao.org.

Gohagu, Y., N.S. Ai and P. Siahaan. 2016. Konsentrasi klorofil pada beberapa varietas tanaman Puring (Codiaeum varigatum L.). Jurnal Mipa Unsrat Online., 5:76-80.

Guo, R., W.P. Hao., D.Z. Gong., X.L. Zhong and F.X. Gu. 2012. Effect of water stress on germination and growth of linseed seedling (Linum usitatissimum L.) photosynthetic efficiency and accumulation of metabolites. Journal of Agricultural Science., 4:253-265.

Gupta, B. and B. Huang. 2014. Mechanism of salinity tolerance in plants: Physiological, biochemical, and molecular characterization. International Journal of Genomics., 2014: 1-18.

Ikhwani., E. Suhartatik and A.K. Makarim. 2010. Pengaruh waktu, lama, dan kekeruhan air rendaman terhadap pertumbuhan dan hasil padi sawah IR64-sub1. Penelitian Pertanian Tanaman Pangan., 29:63-71.

Kawano, N., O. Ito and J. Sakagami. 2008. Relationship between shoot elongation and dry weight during submergence in Oryza sativa L. and O.glaberrima Steud. Rice cultivars. Plant Production Science., 11:316-323.
Kementerian Pertanian. 2016. Data kementan selaras dengan data BPS. http://www. pertanian. go.id/ap_posts/detil/1181/2017/09/28/09/30/0 5/Data\%20 Kementan\% 20Selaras\%20 Dengan \%20Data\%20BPS.

Kementerian Pertanian. 2017. Produksi, luas Panen, dan produktivitas padi di Indonesia, 20132017. Jakarta: Kementerian Pertanian.

Kurniasih, B., H. Greenway and T.D. Colmer. 2017. Energetics of acclimation to $\mathrm{NaCl}$ by submerged, anoxic rice seedlings. Annals of Botany., 119:129-142.

Kurniawati, S., N. Khumaida., S.W. Ardie., N.S. Hartati and E. Sudarmonowati. 2014. Pola akumulasi prolin dan poliamin beberapa aksesi tanaman terung pada cekaman kekeringan. $J$. Agron Indonesia., 42:136-141.

Lakitan, B. 1993. Dasar-dasar fisiologi tumbuhan. Jakarta: Raja Grafindo Persada.

Mareja, H.E. 2015. Tanah dan iklim untuk pertanaman padi. https: //cybex.pertanian.go.id/materi lokakita/detail/12163/tanah-dan-iklim-untukpertanaman-padi/.

Mass, E.V. and G. J. Hoffman. 1997. Crop salt tolerance. Current assessment. ASCE Journal of Irrigation Drainage Division., 103:113134.

Muflikhah, N. 2018. Pertumbuhan dan hasil padi (Oryza sativa L.) Situ bagendit di ledokan dan guludan dengan pengairan salin di lahan sawah Dusun Baros, Bantul, Yogyakarta. Tesis. Program pascasarjana, Fakultas Pertanian, Universitas Gadjah Mada, Yogyakarta.

Muis, A., D. Indradewa and J. Widada. 2013. Pengaruh inokulasi mikoriza arbuskula terhadap pertumbuhan dan hasil kedelai (Glycine max (L.) Merrill) pada berbagai interval penyiraman. Vegetalika., 2:7-20.

Munns, R. and M. Tester. 2008. Mechanisms of salinity tolerance. Annu Rev Plant Biol., 59: 651-681.

Peni, D.K., Solichatun and E. Anggarwulan. 2004. Pertumbuhan, kadar klorofil-karotenoid, saponin, aktivitas nitrat reduktase antinganting (Acalypha indica L.) pada Konsentrasi Asam Giberelat (GA3) yang Berbeda. Biofarmasi., 2:1-8.

Rachmawati, D. and E. Retnaningrum. 2013. Pengaruh tinggi dan lamanya penggenangan terhadap pertumbuhan padi kultivar sintanur dan dinamika populasi rhizobakteria pemfiksasi nitrogen non simbiosis. Bionaturra - Jurnal Ilmu-ilmu Hayati dan Fisik., 15:117-125. 
Rad, H.E., F. Aref., M. Khaledian., M. Razaei., E. Amin and O.Y. Falakdehy. 2011. The effects of salinity at different growth stage on rice yield. ICID $21^{\text {th }}$ International Congress on Irrigarion and Drainage (2011).

Radanielson, A.M., O. Angeles., T. Li., A.M. Ismail and D.S. Gaydon. 2017. Describing the physiological responses of different rice genotypes to salt stress using sigmoid and piecewise linear functions. Field Crop Research., 2017:1-11.

Rivaldi. 2015. Pertumbuhan dan hasil padi (Oryza sativa $\mathrm{L}$.) salibu varietas hibrida pada tinggi dan waktu Penggenangan. Artikel Ilmiah. Fakultas Pertanian, Universitas Tamansiswa. Padang.

Rusd, A.M.I. 2011. Pengujian Toleransi Padi (Oryza sativa L.) terhadap salinitas pada fase perkecambahan. Skripsi. Institut Pertanian Bogor, Bogor.

Sakagami, J., Y. Joho and C. Sone. 2013. Complete submergence escape with shoot elongation ability by underwater photosynthesis in Africa rice, Oryza glaberrima Steud. Field Crops Research., 152:17-26.

Sarkar, R.K., J.N. Reddy., S.G. Sharma and A.M. Ismail. 2006. Physiological basis of submergence tolerance in rice and implication for crop Improvement. Current Science Journal., 91:899-906.

Sasmita, R.K.D. 2006. Dampak pengelolaan fisik tanah terhadap produksi jagung (Zea mays L.) dan efisiensi pemupukan nitrogen dalam sistem pertanian surjan di vertisol. Tesis. Sekolah Pascasarjana, Universitas Gadjah Mada, Yogyakarta.
Sudaryono. 2017. Teknologi produksi ubikayu di lahan pasang surut Kalimantan Selatan. Makalah. Badan Penelitian dan Pengembangan Pertanian, Pusat Penelitian dan Pengembangan Tanaman Pangan, Balai Penelitian Tanaman Aneka Kacang dan Umbi, Malang.

Susilawati, A. and D. Nursyamsi. 2014. Sistem surjan: kearifan lokal petani lahan pasang surut dalam mengantisipasi perubahan iklim. Jurnal sumberdaya lahan., 8:31-42.

Sutaryo, B. 2012. Ekspresi daya hasil dan beberapa karakter agronomi enam padi hibrida indica di lahan sawah berpengairan teknis. Ilmu Pertanian., 15:19-29.

Syamsuddin, D. Indradewa., B.H. Sunarminto and P. Yudono. 2011. Pertumbuhan dan hasil dua kuultivar padi dan berbagai jarak tanam pada sistem pengairan genangan dalam Parit. $J$. Agroland., 18:155-161.

Tubur, H.W., M.A.Chozin., E. Santosa and A. Junaedi. 2012. Respon agronomi varietas padi terhadap periode kekeringan pada sistem sawah. $J$. Agron Indonesia., 40:167-173.

Yoshiva, S. and L. Castaneda. 1969. Partial replacement of potassium by sodium in the rice plant under weakly saline conditions. Soil science and plant nutrition., 15:183-186.

Zeng, L. and M.C. Shannon. 2000. Effects of salinity on grain yield and yield components of rice at different seeding densities. Journal Agron., 92:418-423.

Zeng, L. 2005. Exploration of relationships between physiological parameters and growth Performance of rice (Oryza sativa L.) seedlings under salinity stress using multivariate analysis. Plant and Soil., 268:51-59. 